\title{
Pollen grain morphology of Fabaceae in the Special Protection Area (SPA) Pau-de-Fruta, Diamantina, Minas Gerais, Brazil
}

\author{
CYNTHIA F.P. DA LUZ ${ }^{1}$, ERICA S. MAKI ${ }^{1}$, INGRID HORÁK-TERRA ${ }^{2}$, \\ PABLO VIDAL-TORRADO $^{2}$ and CARLOS VICTOR MENDONÇA FILHO ${ }^{3}$ \\ ${ }^{1}$ Instituto de Botânica, Núcleo de Pesquisa em Palinologia, Avenida Miguel Stéfano, 3687, 04301-902 São Paulo, SP, Brasil \\ ${ }^{2}$ Departamento de Ciência do Solo, Escola Superior de Agricultura "Luiz de Queiroz", \\ Universidade de São Paulo, ESALQ/USP, Av. Pádua Dias, 11, Caixa Postal 9, 13418-900 Piracicaba, SP, Brasil \\ ${ }^{3}$ Departamento de Ciências Biológicas, Universidade Federal dos Vales do Jequitinhonha e Mucuri/UFVJM, \\ Campus JK, Rodovia BR-367, 39100-000 Diamantina, MG, Brasil
}

Manuscript received on July 29, 2011; accepted for publication on April 10, 2012

\begin{abstract}
The presented paper considered the pollen morphology of thirteen species belonging to seven genera of the Fabaceae family occurring in the Pau-de-Fruta Special Protection Area (SPA), Diamantina, state of Minas Gerais, Brazil. The pollen grains of six species of Chamaecrista [C. cathartica (Mart.) H.S. Irwin \& Barneby, C. debilis Vogel, C. flexuosa (L.) Greene, C. hedysaroides (Vogel) H.S. Irwin \& Barneby, C. glandulosa (L.) Greene, and C. papillata H.S. Irwin \& Barneby] have a similar morphology, characterized by three long colporated apertures with a central constriction. The species share specific morphological features regarding pollen size, endoaperture type (circular, lalongate or lolongate) and SEM ornamentation patterns of the exine (rugulate with perforations or perforate). Andira fraxinifolia Benth., Dalbergia miscolobium Benth, Galactia martii DC, Periandra mediterranea (Vell.) Taub., Senna rugosa (G.Don) H.S. Irwin \& Barneby and Zornia diphylla (L.) Pers showed different pollen types in small to large size; oblate spheroidal to prolate form; colpus or colporus apertures; circular, lalongate or lolongate endoapertures and distinctive SEM ornamentation patterns of the exine (perforate, microreticulate, reticulate or rugulate with perforations). Only Stryphnodendron adstringens (Mart.) Coville presents polyads. The pollen morphology variation of these species allowed the Fabaceae family to be characterized as eurypalynous in the SPA Pau-de-Fruta.
\end{abstract}

Key words: Espinhaço Southern Mountain Range, Fabaceae, palynology, pollen morphology.

\section{INTRODUCTION}

The family Fabaceae Lindl. (sensu APG II 2003, APG III 2009) is the third largest family of Angiospermae, second in economic importance of agriculture and widespread in the world, comprising about 727 genera and 19,325 species (Lewis et al. 2005, Wojciechowski 2003). In Brazil,

Correspondence to: Cynthia Fernandes Pinto da Luz

E-mail:cyluz@yahoo.com.br an estimated number of 200 genera and 1,500 species occur in almost all vegetation formations from the Amazon region to the south of the country. In most natural ecosystems in Brazil, Fabaceae is included among the main families (Barroso et al. 1991, Souza and Lorenzi 2005). Many species are pioneers and heliophytes, while others occur in more humid and darker environments and can be selective hygrophytes, or xerophytes aphilas. The 
Fabaceae have distinct well-developed floral traits that result in a diversity of pollination mechanisms (Stirton 1981).

The Fabaceae is commonly found in the Special Protection Area (SPA) Pau-de-Fruta, totaling thirteen species, with herbaceous, shrubs or arboreal representatives (Mendonça Filho 2005, Silva et al. 2005). Inserted in the Espinhaço Southern Mountain Range, the SPA Pau-de-Fruta belongs to Companhia de Saneamento de Minas Gerais (COPASA - MG), located $6 \mathrm{~km}$ from the city of Diamantina. It stretches over 1,700 ha located in the watershed of the Córrego das Pedras, a source used to supply water to the population of the Diamantina city. It consists of flat surfaces interspersed with outcrops of quartz rocks at an average altitude of around 1,366 m a.s.1 with mild temperatures in most part of the year (annual average of $19.0^{\circ} \mathrm{C}$ ), the monthly average of the coldest month is $16.1^{\circ} \mathrm{C}$ (July) and the hottest, $21.3^{\circ} \mathrm{C}$ (January). The average annual precipitation is $1,351 \mathrm{~mm}$ (Neves et al. 2005). The SPA Pau-deFruta has unique geo-morphological features of approximately 81.75 ha occupied by Quaternary peatlands (Campos et al. 2010). The predominant phytophyisiognomy in the area is a humid grassland due to the upwelling of groundwater. It is characterized by the predominance of herbaceous species, and rare shrubs or trees. However, the occurrence of by grassland surrounded "capões" is common, as well as small forest fragments usually associated with wetlands (Ribeiro and Walter 1998, Mendonça Filho 2005, Horak 2009).

The morphology of the Fabaceae pollen is relatively well known. In Brazil, taxonomic studies based on the palynology of the family were developed by Barth (1964) for the arboreal flora of Santa Catarina state; by Melhem $(1966,1968,1971)$ and Salgado-Labouriau (1973) for species of the Cerrado; by Silvestre-Capelato and Melhem (1997) for the flora of a preserved area in São Paulo state; by Souza et al. (2004) for a "Restinga" vegetation (coastal tropical forest) of Rio de Janeiro state and by Carreira et al. (1996) for the Brazilian Amazon, in addition to the compendium on the Fabaceae pollen aimed at the apiculture sector presented by Moreti et al. (2007a, b).

The present study aims to attain the palynological characterization of thirteen species belonging to seven genera of Fabaceae occurring in the SPA of Pau-de-Fruta, Diamantina, Minas Gerais State, Brazil.

\section{MATERIALS AND METHODS}

Fertile individuals of Fabaceae were collected in the Special Protection Area (SPA) Pau-deFruta and processed within the usual methods in botany (Mori et al. 1989). Three samples of each species were pressed separately in a newspaper and dried in a drying kiln for three days. Exsiccate specimens were prepared and incorporated into the Herbarium of the Universidade Federal dos Vales do Jequitinhonha e Mucuri (UFVJM, Herbário DIAM). Only for the Dalbergia miscolobium Benth, which showed insufficient pollen material, the flower buds were removed from exsiccate specimens from the Herbarium Científico do Estado "Maria Eneyda P. Kauffmann Fidalgo" (SP) of the Botanical Institute of São Paulo - Brazil.

The following species were investigated: Andira fraxinifolia Benth. - Brasil. Minas Gerais: Diamantina, SPA Pau-de-Fruta, 13-I-2009, Horák et al. 34-4a (DIAM1969). Chamaecrista cathartica (Mart.) H.S.Irwin \& Barneby. - Brasil. Minas Gerais: Diamantina, SPA Pau-de-Fruta, 12-VIII-2008, Horák 56-1a (DIAM1970). Chamaecrista debilis (Vog.) Irwin \& Barneby. - Brasil. Minas Gerais: Diamantina, SPA Pau-de-Fruta, 23-X-2008, Horák 34-3ª (DIAM 1971). Chamaecrista flexuosa (L.) Greene. - Brasil. Minas Gerais: Diamantina, SPA Pau-de-Fruta, 23X-2008, Horák 43-3ª (DIAM1972). Chamaecrista glandulosa (L.) Greene. - Brasil. Minas Gerais: Diamantina, SPA Pau-de-Fruta, 13-I-2009, Horák et al. C (DIAM1973). Chamaecrista hedysaroides 
(Vogel) H.S. Irwin \& Barneby. - Brasil. Minas Gerais: Diamantina, SPA Pau-de-Fruta, 13-I-2009, Horák et al. 38-4a (DIAM 1974). Chamaecrista papillata H.S. Irwin \& Barneby. - Brasil. Minas Gerais: Diamantina, SPA Pau-de-Fruta, 19-VIII-2008, S.C. Bibiano, C.V. Mendonça \& B.M. Santos 5 (DIAM1975). Dalbergia miscolobium Benth. - Brasil. Minas Gerais: Diamantina, Road of Mendanha; 28-I-1969, H. S. Irwin et al. s.n. (SP117908). Galactia martii DC. - Brasil. Minas Gerais: Diamantina, SPA Paude-Fruta, 23-X-2008, Horák 36-3ª (DIAM1977). Periandra mediterranea (Vell.) Taub. - Brasil. Minas Gerais: Diamantina, SPA Pau-de-Fruta, 23X-2008, Horák 5-3a (DIAM1978). Senna rugosa (G.Don) H.S. Irwin \& Barneby. - Brasil. Minas Gerais: Diamantina, SPA Pau-de-Fruta, 12-VIII2008, Horák 39-1ª (DIAM1979). Stryphnodendron adstringens (Mart.) Coville. - Brasil. Minas Gerais: Diamantina, SPA Pau-de-Fruta, 23-X-2008, Horák 11-3 ${ }^{\mathrm{a}}$ (DIAM1980). Zornia diphylla (L.) Pers. Brasil. Minas Gerais: Diamantina, SPA Pau-deFruta, 23-X-2008, Horák 77-3ª (DIAM1981).

Pollen grains were acetolysed following Erdtman (1960). Pollen dimension averages were derived from measurements of 25 pollen grains per sample. Measurements of morphological structures were based upon ten pollen grains per sample. Scanning electron microscope images of the non acetolysed pollen grains were obtained using a PHILIPS XL 20 microscope of the Instituto de Botânica. The pollen grains were spread directly on the microscope stubs, and sputtered with a $20 \mathrm{~nm}$ thick gold layer. Terminology follows that of Barth and Melhem (1988) and Punt et al. (2007).

\section{RESULTS}

The description of pollen grains and polyads morphology of the thirteen species of Fabaceae occurring in SPA Pau-de-Fruta, Diamantina, Minas Gerais, Brazil, is presented. The size of pollen grains and polyads is presented in Tables 2, 3, 4, 5 and Figures 1 and 2.
ANDIRA JUSS.

\section{Andira fraxinifolia Benth.}

Figures 3-9

Pollen grains of small size, isopolar, of radial symmetry, prolate spheroidal, amb subcircular, 3-colporate, longiaperturate, colpi with pointed apices, no central constriction, and without a covering exinous membrane, endoaperture lalongate, well delimited, sexine microreticulate with smaller brochi next to the apertural area, looking like a psilate margo, sexine slightly thicker than the nexine.

Chamaecrista (L.) Moench.

\section{Chamaecrista cathartica (Mart.) H.S.Irwin \& Barneby}

Figures 10-16

Pollen grains of large size, isopolar, of radial symmetry, subprolate, amb subcircular, 3-colporate, longiaperturate, colpi with pointed apices, sometimes looking like syncolporate, with central constriction, and with a covering granulate exinous membrane, endoaperture circular, difficult to see, sexine perforate, with perforations disappearing next to the apertural area, looking like a psilate margo, sexine twice thicker than the nexine.

\section{Chamaecrista debilis (Vog.) Irwin \& Barneby} Figures 17-21

Pollen grains of large size, isopolar, of radial symmetry, prolate, amb subcircular, 3-colporate, longiaperturate, colpi with pointed apices, with psilate margo, sometimes looking like syncolporate, with central constriction, and with a covering granulate exinous membrane, endoaperture lalongate, difficult to see, sexine rugulate with perforations, sexine with the same thickness of the nexine.

\section{Chamaecrista flexuosa (L.) Greene}

Figures 22-24

Pollen grains of large size, isopolar, of radial symmetry, prolate, amb subcircular, 3-colporate, longiaperturate, colpi with pointed apices, with psilate 
margo, sometimes looking like syncolporate, with central constriction, and with a covering granulate exinous membrane, endoaperture lalongate remarkable narrow, sexine rugulate with perforations, sexine twice thicker than the nexine.

Comments: The pollen grains of C. flexuosa crumple and wrinkle easily and are difficult to observe in polar view.

\section{Chamaecrista glandulosa (L.) Greene}

Figures 25-28

Pollen grains of large to medium size, isopolar, of radial symmetry, subprolate, amb subcircular, 3-syncolporate, colpi with psilate margo, with central constriction, and with a covering rugulate exinous membrane, endoaperture circular, well delimited, sexine rugulate with perforations, sexine slightly thicker than the nexine.

\section{Chamaecrista hedysaroides (Vogel) H.S. Irwin \& Barneby}

Figures 29-34

Pollen grains of small size, isopolar, of radial symmetry, subprolate, amb subcircular slightly sinu-aperturate, 3-colporate, longiaperturate, colpi with pointed apices, with psilate margo, with central constriction, and with a covering granulate exinous membrane, endoaperture lalongate, difficult to see, sexine rugulate with perforations, sexine slightly thicker than the nexine.

\section{Chamaecrista papillata H.S. Irwin \& Barneby}

Figures 35-40

Pollen grains of medium size, isopolar, of radial symmetry, subprolate, amb subcircular, 3-colporate, longiaperturate, colpi with pointed apices, sometimes looking like syncolporate, with central constriction, and with a covering granulate exinous membrane, endoaperture lolongate, well delimited, sexine perfurate with perforations disappearing next to the apertural area, looking like a psilate margo, sexine thicker than the nexine.
Dalbergia L.f.

\section{Dalbergia miscolobium Benth}

Figures 41-45

Pollen grains of small size, isopolar, of radial symmetry, subprolate, amb subtriangular, 3-colporate, longiaperturate, colpi with pointed apices, no central constriction, and without a covering exinous membrane or margo, endoaperture circular to lolongate, well delimited, sexine perfurate, sexine twice thicker than the nexine.

Galactia P. Browne

\section{Galactia martii DC}

Figures 46-53

Pollen grains of medium size, isopolar, of radial symmetry, oblate spheroidal, amb triangular, 3-colporate, longiaperturate, colpi with pointed apices and an evident psilate margo, with a slight central constriction, and without a covering exinous membrane, endoaperture lalongate, difficult to see, sexine bireticulate (the suprareticulum is supported by a microreticulate tectum observed in SEM), heterobrochate with brochi smaller next to the margo area, sexine twice thicker than the nexine.

Periandra Mart. ex Benth.

\section{Periandra mediterranea (Vell.) Taub.}

Figures 54-59

Pollen grains of medium size, isopolar, of radial symmetry, prolate spheroidal, amb subcircular, 3-colporate, longiaperturate, colpi with pointed apices, and with an evident psilate margo, very thicker in the equatorial area, no central constriction, and without a covering exinous membrane, endoaperture lalongate, well delimited, sexine microreticulate at the mesocolpium and perfurate at the apocolpium, sexine thicker than the nexine.

Senna Mill.

\section{Senna rugosa (G.Don) H.S. Irwin \& Barneby} Figures 60-65

Pollen grains of large size, isopolar and heteropolar, of radial and bilateral symmetry (rare 2-aperturates), 
TABLE I

Measures $(\mu \mathrm{m})$ in equatorial view of pollen grains of species of the Fabaceae family from the Special Protection Area (SPA) Pau-de-Fruta, Diamantina, Minas Gerais $(n=25)$. $x$ - arithmetic mean, $s_{x}-$ medium standard deviation, V- coefficient of variability, CI- confidence interval 95\%, P- polar diameter, E - equatorial diameter.

\begin{tabular}{|c|c|c|c|c|c|c|c|c|c|}
\hline \multirow{2}{*}{ Taxon } & \multicolumn{4}{|c|}{ Polar Diameter } & \multicolumn{4}{|c|}{ Equatorial Diameter } & \multirow{2}{*}{$\mathbf{P} / \mathbf{E}$} \\
\hline & $\mathbf{x}$ & $\mathbf{s}_{\mathbf{x}}$ & $\mathrm{V} \%$ & CI95\% & $\mathbf{x}$ & $\mathbf{s}_{\mathbf{x}}$ & $\mathrm{V} \%$ & CI95\% & \\
\hline Andira fraxinifolia & 20.2 & 0.1 & 1.6 & $20.0-20.3$ & 19.6 & 0.1 & 2.0 & $19.4-19.8$ & 1.03 \\
\hline Chamaecrista cathartica & 51.4 & 0.4 & 4.0 & $50.5-52.2$ & 40.9 & 0.5 & 6.5 & $39.8-41.9$ & 1.26 \\
\hline Chamaecrista debilis & 60.9 & 0.3 & 2.5 & $60.3-61.5$ & 44.9 & 0.1 & 1.5 & $44.6-45.1$ & 1.36 \\
\hline Chamaecrista flexuosa & 54.7 & 0.5 & 4.7 & $53.7-55.7$ & 36.6 & 0.5 & 7.6 & $35.5-37.7$ & 1.49 \\
\hline Chamaecrista glandulosa & 49.9 & 0.4 & 4.3 & $49.0-50.8$ & 38.8 & 0.4 & 5.5 & $37.9-39.6$ & 1.29 \\
\hline Chamaecrista hedysaroides & 25.1 & 0.3 & 6.0 & $24.5-25.7$ & 20.5 & 0.2 & 5.7 & $20.0-21.0$ & 1.22 \\
\hline Chamaecrista papillata & 44.9 & 0.3 & 3.6 & $44.2-45.5$ & 36.5 & 0.4 & 4.8 & $35.8-37.2$ & 1.23 \\
\hline Dalbergia miscolobium & 19.4 & 0.3 & 8.0 & $18.8-20.1$ & 15.3 & 0.2 & 7.5 & $14.9-15.8$ & 1.27 \\
\hline Galactia martii & 34.4 & 0.4 & 6.2 & $33.5-35.3$ & 37.3 & 0.5 & 6.2 & $36.4-38.3$ & 0.92 \\
\hline Periandra mediterranea & 44.4 & 0.7 & 7.3 & $43.1-45.8$ & 41.4 & 0.6 & 7.1 & $40.2-42.6$ & 1.07 \\
\hline Senna rugosa (3-colporate) & 61.6 & 0.7 & 7.9 & $60.2-63.0$ & 45.5 & 0.6 & 9.8 & $44.2-46.8$ & 1.35 \\
\hline Senna rugosa (4-colporate) & 62.4 & 0.6 & 5.6 & $61.1-63.6$ & 44.6 & 0.6 & 8.2 & $43.3-46.0$ & 1.40 \\
\hline Zornia diphylla & 37.2 & 0.5 & 6.7 & $36.2-38.3$ & 24.1 & 0.4 & 7.5 & $23.4-24.9$ & 1.54 \\
\hline
\end{tabular}

TABLE II

Arithmetic average of measures $(\mu \mathrm{m})$ of colpus, presence or not of margo and thickness of the exine layers of the pollen grains of the Fabaceae family from the Special Protection Area (SPA) Pau-de-Fruta, Diamantina, Minas Gerais (n=10).

\begin{tabular}{lccccccc}
\hline \multirow{2}{*}{\multicolumn{1}{c}{ Taxon }} & \multicolumn{3}{c}{ Colpus } & \multicolumn{2}{c}{ Endoaperture } & \multicolumn{2}{c}{ Exine layers } \\
\cline { 2 - 7 } & Widht & Lenght & Margo & Widht & Lenght & Sexine & Nexine \\
\hline Andira fraxinifolia & 0.70 & 13.97 & No & 6.89 & 4.10 & 0.67 & 0.57 \\
Chamaecrista cathartica & 3.98 & 45.12 & No & 8.26 & 8.5 & 1.15 & 0.55 \\
Chamaecrista debilis & 4.12 & 55.19 & Yes & ---- & ---- & 0.76 & 0.72 \\
Chamaecrista flexuosa & 3.43 & 47.94 & Yes & 9.25 & 0.92 & 1.22 & 0.60 \\
Chamaecrista glandulosa & 3.94 & ---- & Yes & 7.55 & 8.26 & 0.73 & 0.64 \\
Chamaecrista hedysaroides & 1.86 & 21.35 & Yes & ---- & ---- & 1.07 & 0.92 \\
Chamaecrista papillata & 5.96 & 39.57 & No & 7.31 & 9.14 & 0.99 & 0.57 \\
Dalbergia miscolobium & 1.63 & 15.25 & No & 5.66 & 5.9 & 0.79 & 0.39 \\
Galactia martii & 5.51 & 28.77 & Yes & ---- & 1.96 & 0.91 & 0.48 \\
Periandra mediterranea & 6.60 & 35.45 & Yes & 15.38 & 10.77 & 1.67 & 0.56 \\
Senna rugosa (3 colporate) & 6.21 & 48.40 & No & 8.21 & 7.85 & 2.13 & 1.22 \\
Senna rugosa (4 colporate) & 7.41 & 47.47 & No & 8.74 & 8.69 & 2.26 & 1.27 \\
Zornia diphylla & 3.72 & 32.13 & No & ---- & ---- & 0.93 & 0.60 \\
\hline
\end{tabular}

prolate, amb subcircular or quadrangular, longiaperturate, colpi with rounded apices, no central constriction, without a covering exinous membrane or margo, endoaperture circular, difficult to see, sexine rugulate with perforations, sexine twice thicker than the nexine.

Comments: The pollen grains of $S$. rugosa were observed as 3-aperturate (isopolar 3-colporate, 
TABLE III

Measures $(\mu \mathrm{m})$ of the side view (Major axis and Minor axis), front view (Diameter I and Diameter II) and the thickness of the exine layers of the Stryphnodendron adstringens polyads from the Special Protection Area (SPA) Pau-de-Fruta, Diamantina, Minas Gerais ( $=25)$. $x$ - arithmetic mean, $\mathbf{S}_{\mathbf{x}}-$ medium standard deviation, $\mathrm{V}$ - coefficient of variability, $\mathrm{CI}$ - confidence interval $\mathbf{9 5 \%}$.

\begin{tabular}{ccccccc}
\hline & \multicolumn{2}{c}{ Side view } & \multicolumn{2}{c}{ Front view } & \multicolumn{2}{c}{ Exine layers } \\
\cline { 2 - 6 } & Major axis & Minor axis & Diameter I & Diameter II & Sexine & Nexine \\
\hline $\mathrm{x}$ & 44.5 & 30.0 & 38.7 & 34.7 & 0.84 & 0.38 \\
$\mathrm{~S}_{\mathrm{x}}$ & 0.4 & 0.6 & 0.4 & 0.4 & & \\
$\mathrm{~V} \%$ & 4.3 & 9.9 & 5.4 & 6.1 & & \\
CI95\% & $43.7-45.3$ & $28.7-31.2$ & $37.9-39.6$ & $33.8-35.5$ & & \\
\hline
\end{tabular}

heteropolar 3-parasyncolporate and heteropolar 3-sincolporate) or 4-aperturate (isopolar 4-colporate or heteropolar 4-pasyncolporate).

\section{Stryphnodendron Mart.}

\section{Stryphnodendron adstringens (Mart.) Coville}

Figures 66-70

Pollen grains grouped as polyad, acalymmate, medium size, elongated or elliptical in side view and subcircular in frontal view, 16 pollen grains asymmetrically arranged, without differentiation in central or side pollen grains, porus visible only in Transmission electron microscopy (Guinet \& Caccavari 1992), sexine psilate in LM but with smaller rounded verrucae in SEM, sexine thicker than the nexine.

Zornia J.F. Gmel

\section{Zornia diphylla (L.) Pers}

Figures 71-74

Pollen grains of medium size, isopolar, of radial symmetry, prolate, amb subcircular, 3-colpate, longiaperturate, colpi with pointed apices, no central constriction, and with a covering granulate exinous membrane, remarkable psilate operculum, sexine microreticulate with smaller brochi next to the apertural area looking like a psilate margo, sexine thicker than the nexine.

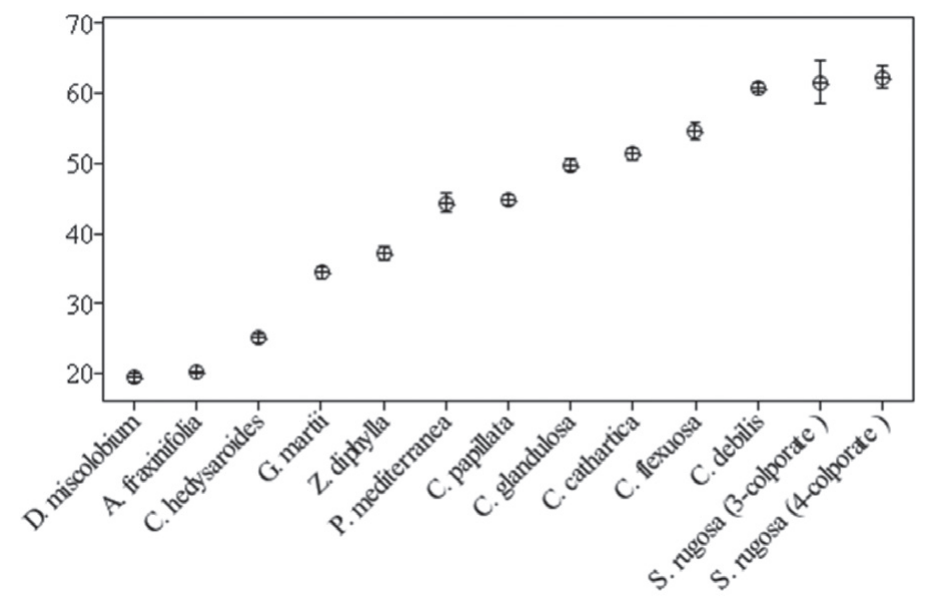

Figure 1 - Representation of confidence interval of mean in 95\% of Polar diameter $(\mu \mathrm{m})$ in equatorial view of the pollen grains of the Fabaceae family from the Special Protection Area (SPA) Pau-de-Fruta, Diamantina, Minas Gerais. The higher and lower boundaries showing the confidence interval; the average circle showing the arithmetic mean. 


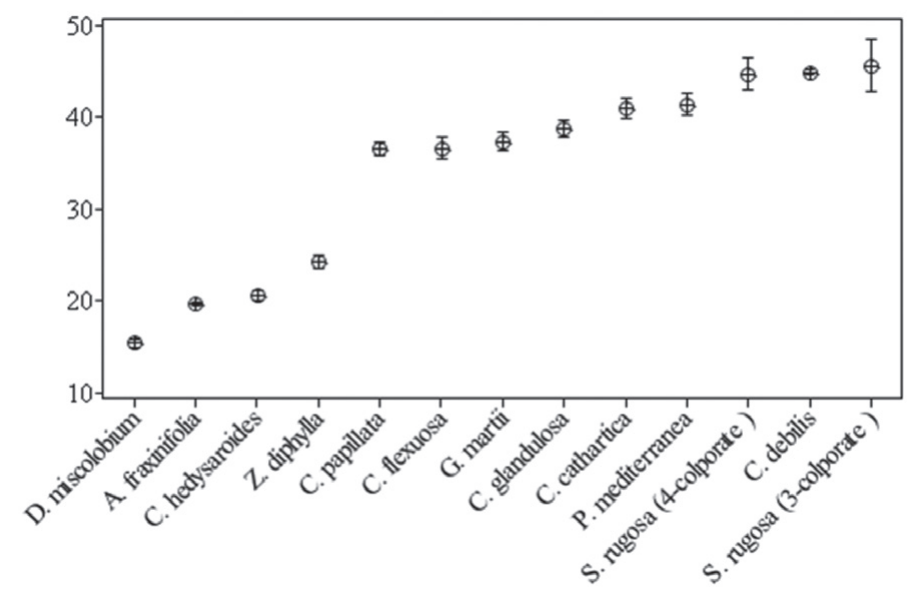

Figure 2 - Representation of confidence interval of mean in $95 \%$ of Equatorial diameter $(\mu \mathrm{m})$ in equatorial view of the pollen grains of the Fabaceae family from the Special Protection Area (SPA) Pau-de-Fruta, Diamantina, Minas Gerais. The higher and lower boundaries showing the confidence interval; the average circle showing the arithmetic mean.

\section{DISCUSSION}

Pollen morphology of Andira fraxinifolia has not been studied previously. However, other Andira species have been the subject of palynological studies developed by Barth (1964), Melhem (1968), Salgado-Labouriau (1973), Roubik and Moreno (1991), Silvestre-Capelato and Melhem (1997) and Carreira et al. (1996). The species studied by Barth (1964) and Silvestre-Capelato and Melhem (1997), A. anthelmia differs from the species described in the present study due to the presence of a equatorial constriction of the colpi, absent in the species analyzed here. Barth (1964) also noted 2-colpate pollen grains, which was not observed in the present study, moreover, the measurements of the diameters were larger than those obtained here. Salgado-Labouriau (1973) studied the pollen morphology of four species of Andira. The author obtained different results in terms of a larger size of pollen grains, a pilate or reticulate ornamentation, the constant presence of psilate margos, and a decrease of the brochi diameter towards the apertures. Carreira et al. (1996) studied pollen grain morphology of Andira multistipula Ducke from the
Amazon region, characterized being psilate and not microreticulate. The pollen material from Andira inermis (W. Wright) HBK studied in Panama by Roubik and Moreno (1991) was characterized as psilate also, and its pollen grains were much smaller than those analyzed here. Melhem (1968) studied four species from the Cerrado (A. humilis, A. laurifolia, A. vermifuga and A. paniculata) and concluded that the genus is stenopalynous.

It was noted that the six taxa of Chamaecrista analyzed showed homogeneity of pollen characteristics, mainly related to the apertures that are very long, 3-colporate and with a central constriction, pointed apices, sometimes giving the impression of binding at the poles, ascertaining the truly syncolporate pollen grains in C. glandulosa only. The main pollen intra-genetic characteristics observed were: shape (subprolate to prolate); amb (slightly sinu-aperturate or not), size of the polar and equatorial diameters (from 20.0 to $61.5 \mu \mathrm{m}$ ) and endoapertures ranging from circular, lalongate to lolongate, but not always clearly visible. $C$. hedysaroides stands out as the only slightly sinuaperturate species, with pollen grain size smaller 

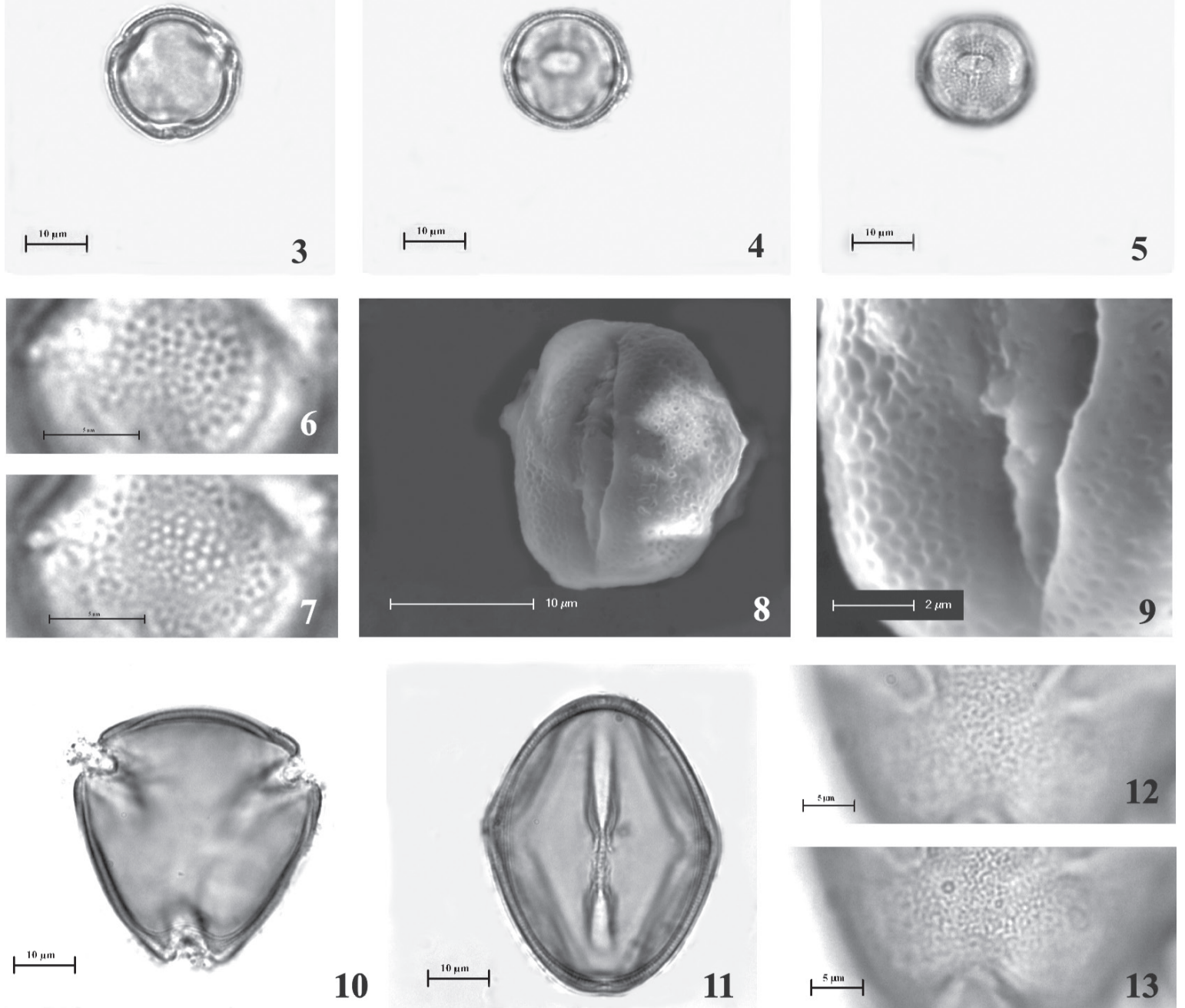

10

11
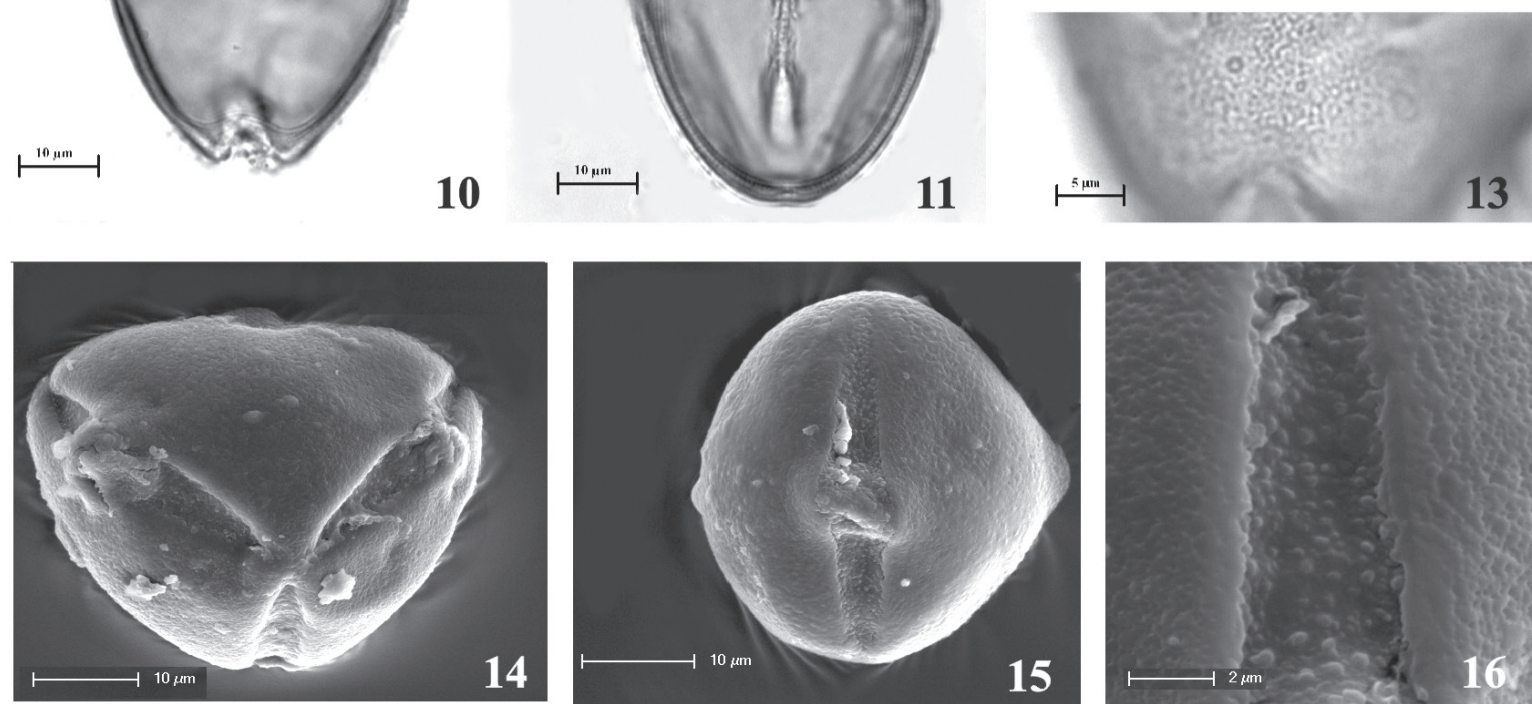

Figures 3-16 - Light and scanning electron micrographs of pollen grains of Andira fraxinifolia and Chamaecrista cathartica. 3-9. Andira fraxinifolia Benth. 3. Polar view, optical section, LM. 4. Equatorial view, optical section, LM. 5. Detail of the endoaperture, LM. 6-7. L.O. in high (6) and low (7) focus. 8. Equatorial view, SEM. 9. Detail of aperture, SEM. 10-16. Chamaecrista cathartica (Mart.) H.S.Irwin \& Barneby. 10. Polar view, optical section, LM. 11. Equatorial view, optical section, LM. 12-13. L.O. in high (12) and low (13) focus. 14. Polar view, SEM. 15. Equatorial view, SEM. 16. Detail of aperture, SEM. Scale bar $=2 \mu \mathrm{m}(9,16) ; 5 \mu \mathrm{m}(6,7,12,13) ; 10 \mu \mathrm{m}(3,4,5,8,10,11,14,15)$. 


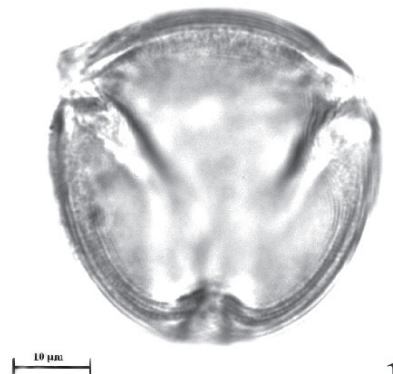

17
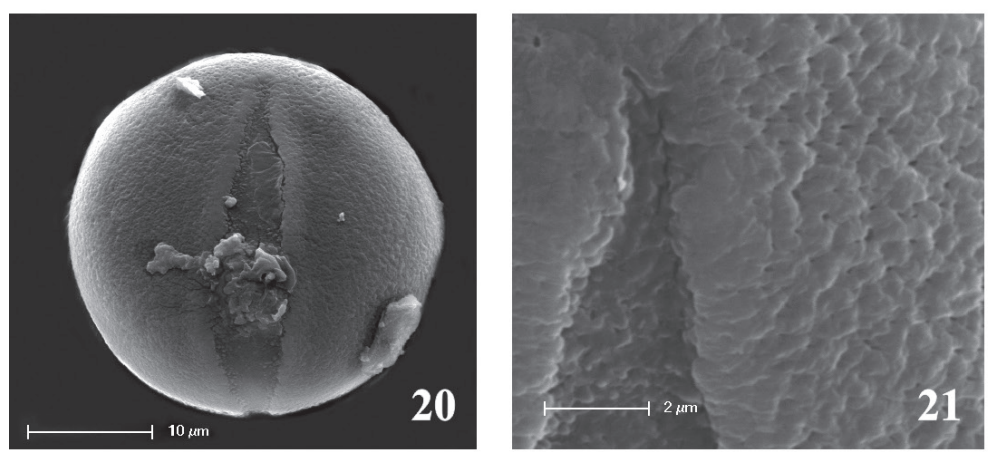

18
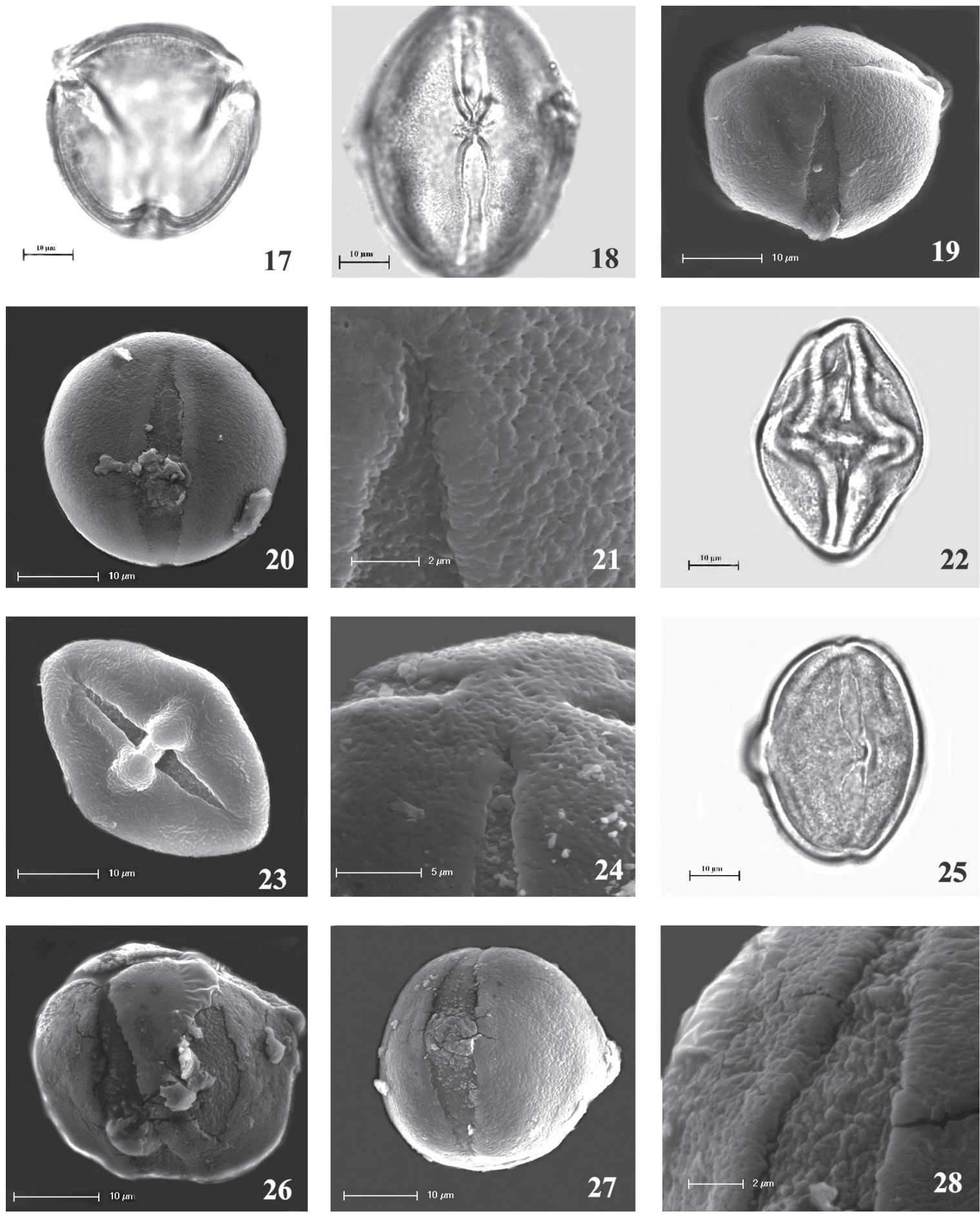

22
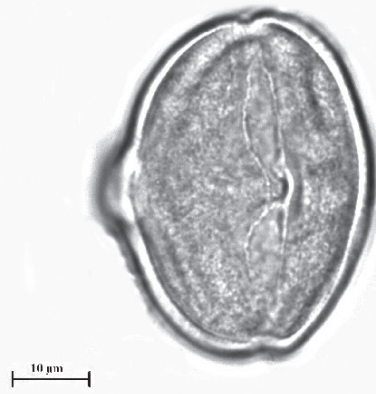

25

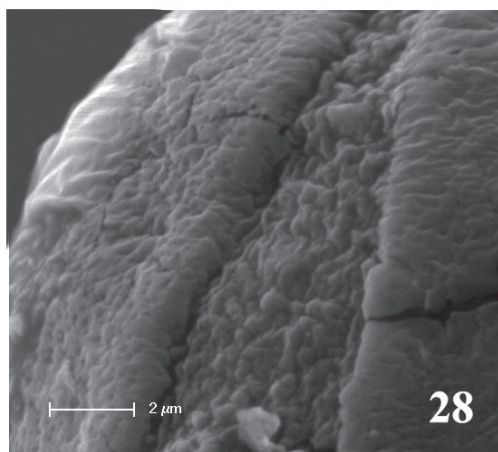

Figures 17-28 - Light and scanning electron micrographs of pollen grains of Chamaecrista debilis, Chamaecrista flexuosa and Chamaecrista glandulosa. 17-21. Chamaecrista debilis (Vog.) Irwin \& Barneby. 17. Polar view, optical section, LM. 18. Equatorial view, optical section, LM. 19. Polar view, SEM. 20. Equatorial view, SEM. 21. Detail of aperture, SEM. 22-24. Chamaecrista flexuosa (L.) Greene. 22. Equatorial view, optical section, LM. 23. Equatorial view, SEM. 24. Detail of apocolpium, SEM. 25-28. Chamaecrista glandulosa (L.) Greene. 25. Equatorial view, optical section, LM. 26. Polar view, SEM. 27. Equatorial view, SEM. 28. Detail of aperture, SEM. Scale bar $=2 \mu \mathrm{m}(21,28) ; 5 \mu \mathrm{m}(24) ; 10 \mu \mathrm{m}(17,18,19,20,22,23,25,26,27)$. 
than $25 \mu \mathrm{m}$. However, shape, amb and size of pollen grains are of lower diagnostic value, as they can vary within the same species and be affected by the preparation method and the environmental conditions of the plants. Pollen grains of $C$. debilis, C. flexuosa and C. glandulosa, can not be distinguished. Its rugula are smaller than of the remaining species and little developed. $C$. cathartica and $C$. papillata differ in terms of the polar and equatorial diameters only. It is noteworthy that the exine ornamentation variations may be observed only using ultrastructural magnification. Therefore, Chamaecrista can be considered as a stenopalynous genus in the SPA Pau-of-Fruta area. Other species of Chamaecrista were analysed by Carreira et al. (1996) and Silvestre-Capelato and Melhem (1997), the latter authors agree with our results, characterizing the genus as stenopalynous. Among the studied species by these authors, two specimens of C. glandulosa showed 3-colporate pollen grains, microreticulate sculpture and smaller diameters. Their microreticulate feature may be attributed to the lack of SEM observation. Syncolporate apertures occurring in the present sample showed, therefore, a variability of the aperture structure in pollen grains of this species. It should be noted, however, the need for further studies involving more specimens of $C$. glandulosa collected in the SPA Pau-de-Fruta to assess the confluence of the colpi.

The Dalbergia miscolobium pollen grains has been studied by Melhem (1968), presenting a similar description, differing in terms of the presence of a margo and lalongate endoapertures, unlike the circular and lolongate ones observed in the present study. Two more species from the Brazilian Cerrado region were there studied also, concluding that the species of Dalbergia could only be distinguished by their diameters. SalgadoLabouriau (1973) studied the same species from the Cerrado previously studied by Melhem (1968), grouping them by their similar pollen morphology into the Andira pollen type, joining the species of Andira and Machaerium. SPA Pau-de-Fruta Dalbergia miscolobium pollen grains differ from that of Andira by the shape, amb, type of endoapertures and exine ornamentation.

The pollen morphology of Galactia martii has not been studied previously. Pollen grains of other species of Galactia were examined by Melhem (1971) and Silvestre-Capelato and Melhem (1997); the palynological description matches, except by the oblate spheroidal form of $G$. martii pollen grains. Melhem (1971) noted a polymorphism of the pollen grain shape of $G$. macrophylla, considering the genus as a stenopalinous one. Carreira et al. (1996) indicated a microreticulate ornamentation of Galactia jussiaeana from the Amazon region, which does not match with the reticulate pattern of $G$. martii. Studying the bee pollen morphology of three species of Galactia, Moreti et al. (2007a) characterized them as small to medium sized, microreticulate and subprolate. As in Carreira et al. (1996), there was no analysis in SEM and in Moreti et al. (2007a) the increase of ultrastructure photos was small, the microreticulate within the brochi of the reticulum were not disclosed, as described in the present analysis.

Pollen morphology of six Brazilian species of Periandra was studied by Funch and Watanabe (1994), among them P. mediterranea, previously studied by Melhem (1971) and Carreira et al. (1996). The data obtained differ from those in terms of smaller sizes of polar and equatorial diameters, and a thinner aperture margo. The microreticulate exine corroborates with Carreira et al. (1996), differing from the reticulate described by Funch and Watanabe (1994). These authors also indicated that the Periandra genus is eurypalynous.

The flowers of Senna rugosa (synonym of Cassia rugosa G Don in Salgado-Labouriau et al. 1965) are heterostylous, presenting three different kinds ofstamens, those with large and medium anthers, besides the staminodia. The data presented by Salgado- 

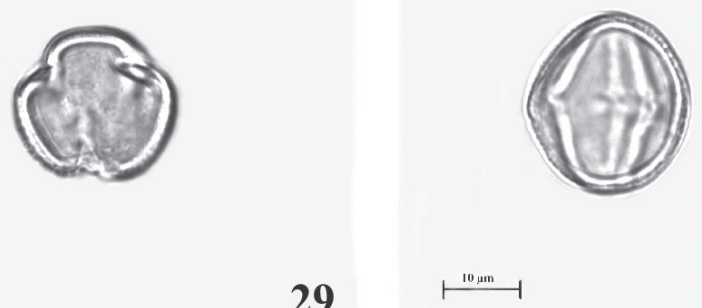

30

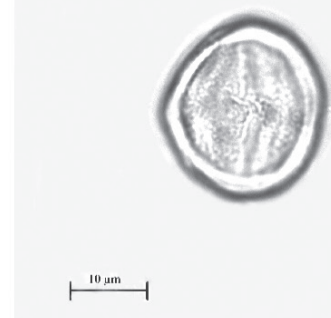

31
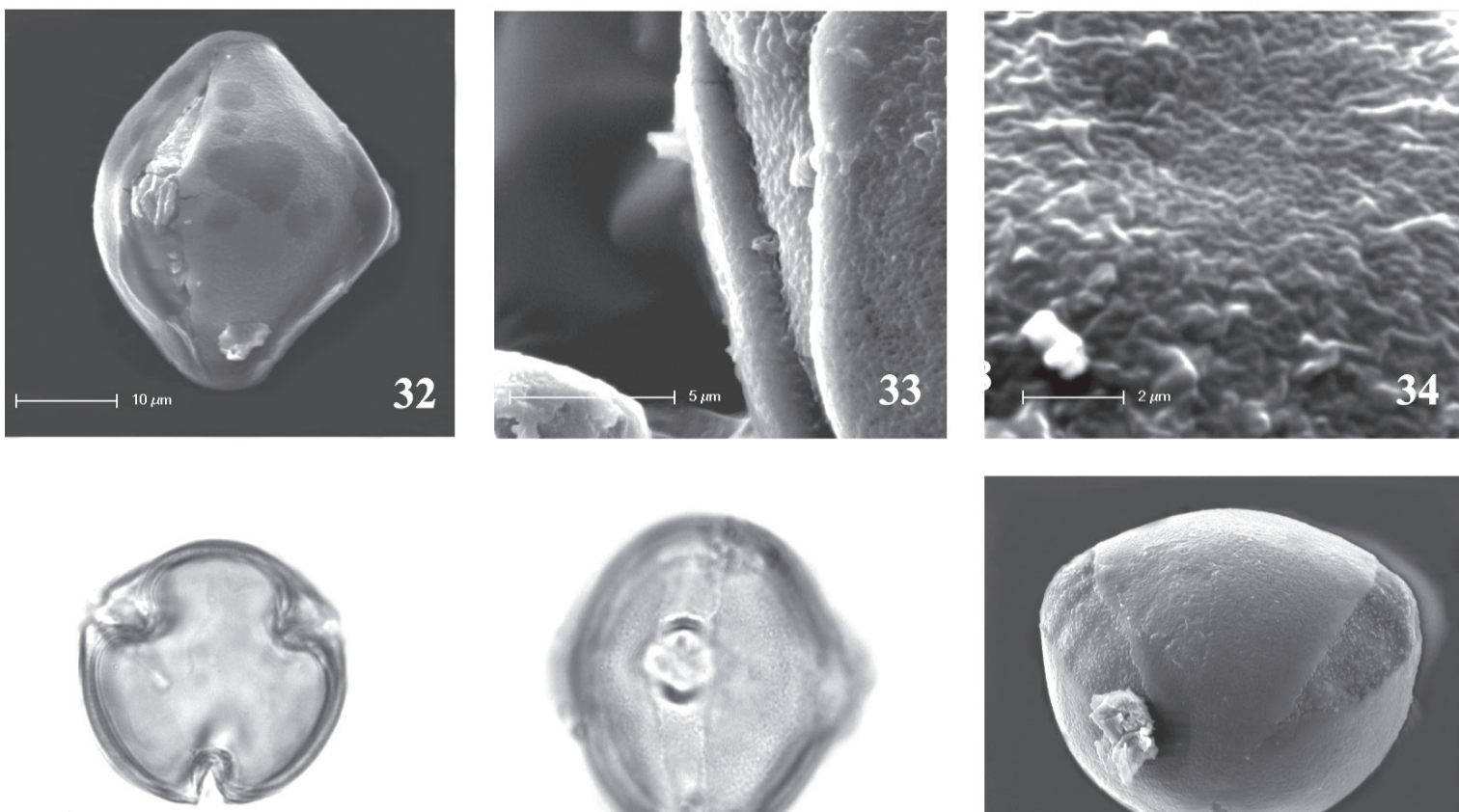
$\stackrel{10 \text { un }}{1}$

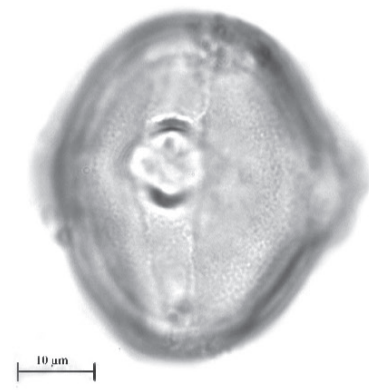

36
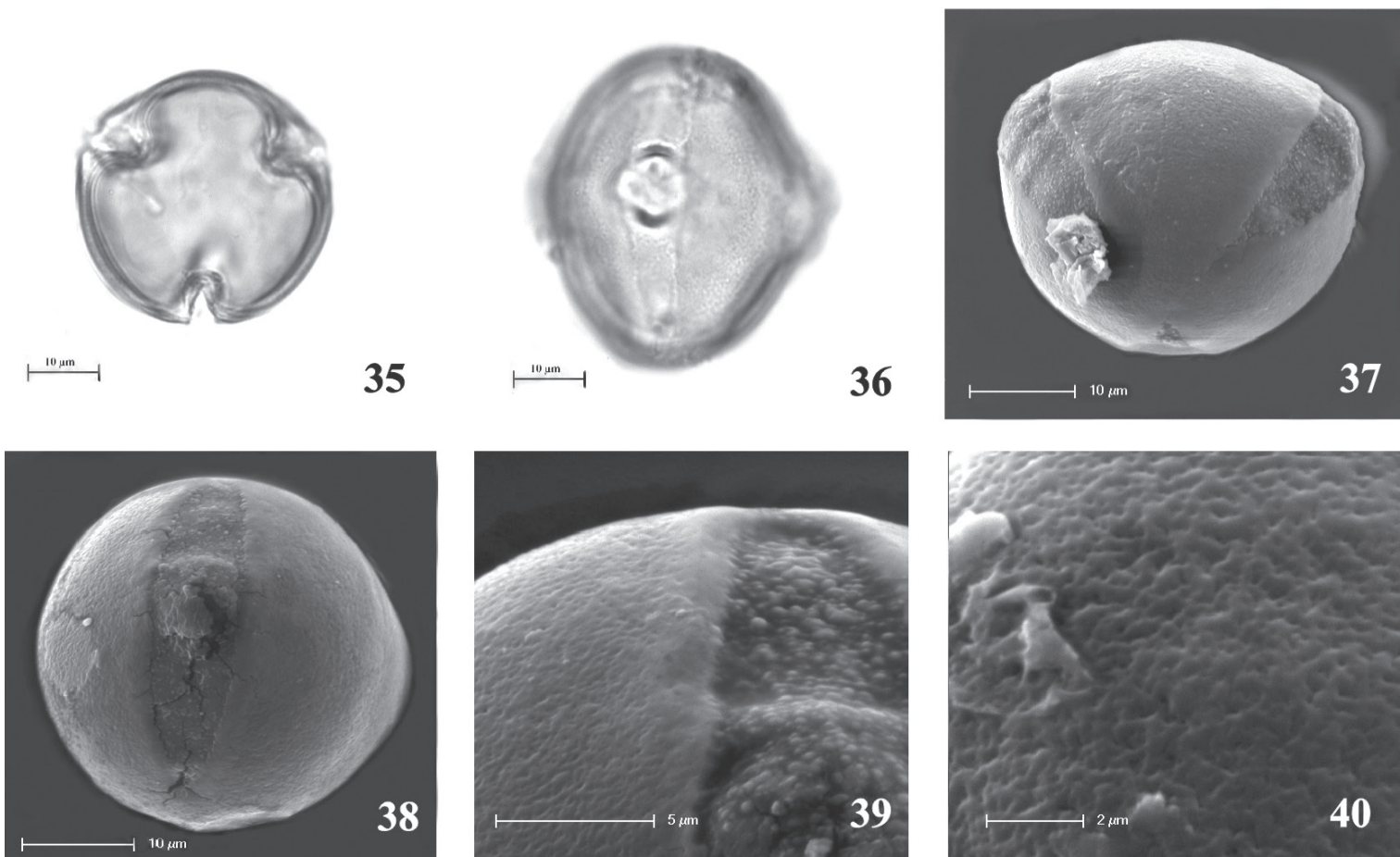

Figures 29-40 - Light and scanning electron micrographs of pollen grains of Chamaecrista hedysaroides and Chamaecrista papillata. 29-34. Chamaecrista hedysaroides (Vogel) H.S. Irwin \& Barneby. 29. Polar view, optical section, LM. 30. Equatorial view, optical section, LM. 31. Detail of endoaperture, LM. 32. Equatorial view, SEM. 33. Detail of aperture, SEM. 34. Detail of ornamentation, SEM. 35-40. Chamaecrista papillata H.S. Irwin \& Barneby. 35. Polar view, optical section, LM. 36. Equatorial view, optical section, LM. 37. Polar view, SEM. 38. Equatorial view, SEM. 39. Detail of aperture, SEM. 40. Detail of ornamentation, SEM. Scale bar $=2 \mu \mathrm{m}(34,40) ; 5 \mu \mathrm{m}(33,39) ; 10 \mu \mathrm{m}(29,30,31,32,35,36,37,38)$. 

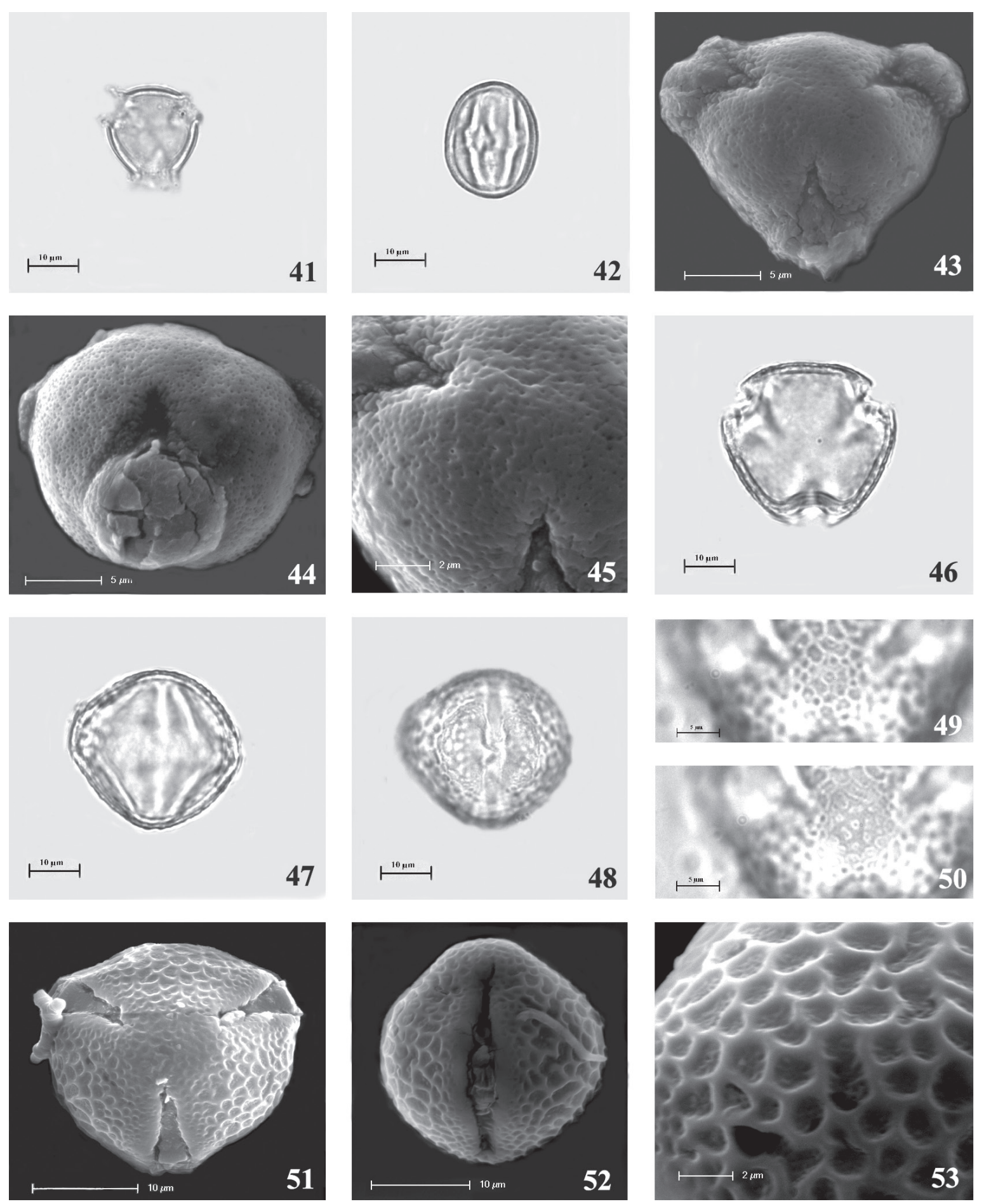

Figures 41-53 - Light and scanning electron micrographs of pollen grains of Dalbergia miscolobium and Galactia martii. 41-45. Dalbergia miscolobium Benth. 41. Polar view, optical section, LM. 42. Equatorial view, optical section, LM. 43. Polar view, SEM. 44. Equatorial view, SEM. 45. Detail of ornamentation, SEM. 46-53. Galactia martii DC. 46. Polar view, optical section, LM. 47. Equatorial view, optical section, LM. 48. Equatorial view, detail of aperture, LM. 49-50. L.O. in high (49) and low (50) focus. 51. Polar view, SEM. 52. Equatorial view, SEM. 53. Detail of ornamentation, SEM. Scale bar $=2 \mu \mathrm{m}(45,53) ; 5 \mu \mathrm{m}(43,44,49,50) ; 10 \mu \mathrm{m}(41,42,46,47,48,51,52)$. 

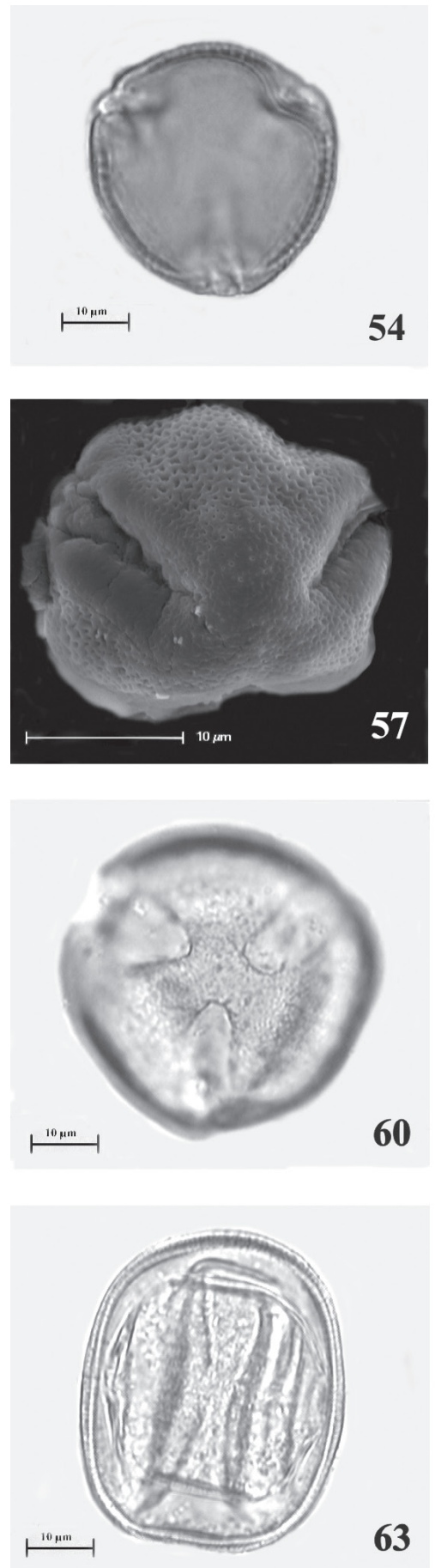

63
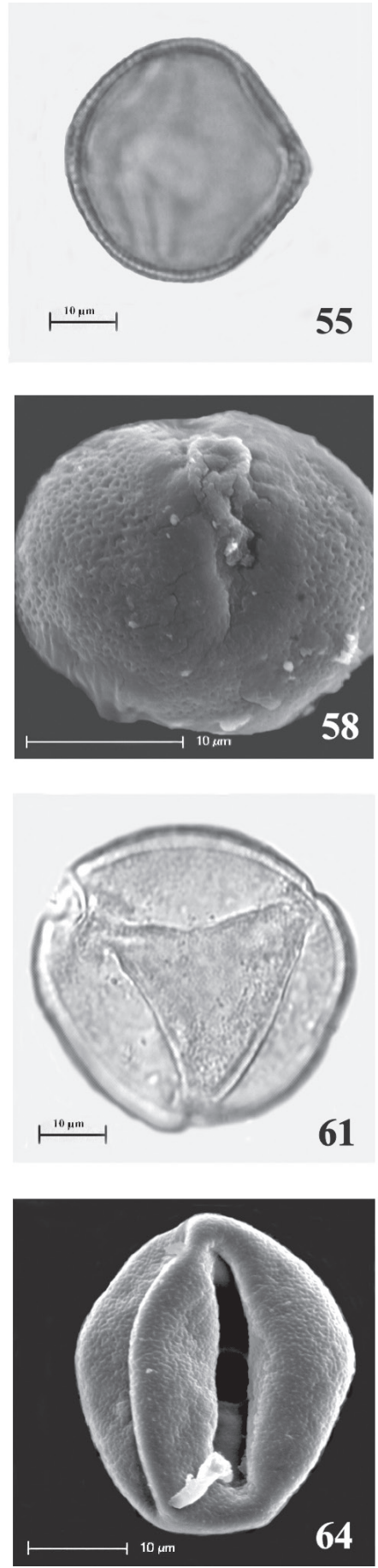
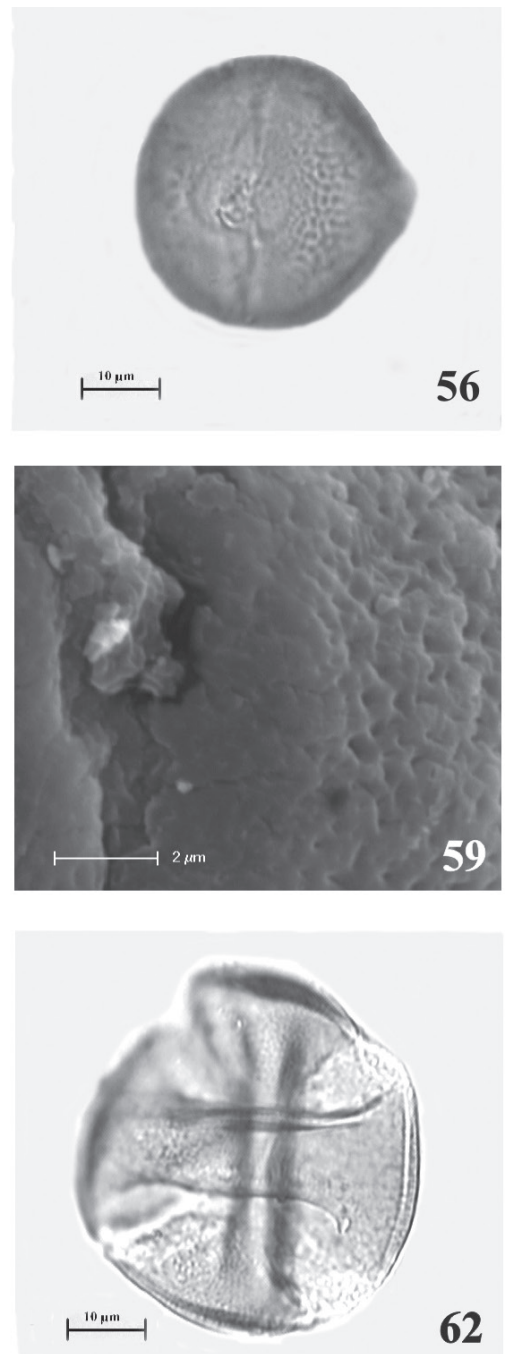

62

Figures 54-65 - Light and scanning electron micrographs of pollen grains of Periandra mediterranea and Senna rugosa. 54-59. Periandra mediterranea (Vell.) Taub. 54. Polar view, optical section, LM. 55. Equatorial view, optical section, LM. 56. Equatorial view, detail of endoaperture, LM. 57. Polar view, SEM. 58. Equatorial view, SEM. 59. Detail of aperture, SEM. 60-65. Senna rugosa (G.Don) H.S. Irwin \& Barneby. 60. Polar view, 3-colporate, heteropolar, detail of apocolpium, LM. 61. Polar view, 3-colporate, heteropolar, detail of apocolpium, other side of the same pollen grain, LM. 62. Polar view, 4-colporate, isopolar, LM. 63. Equatorial view, optical section, 4-colporate, isopolar, LM. 64. Equatorial view, SEM. 65. Detail of ornamentation, SEM. Scale bar $=2 \mu \mathrm{m}(59,65) ; 10 \mu \mathrm{m}(54,55,56,57,58,60,61,62,63,64)$. 
Labouriau et al. (1965) and Salgado-Labouriau (1973) as Cassia rugosa differ from the present specimen by the reticulate ornamentation and the occurrence of pantoaperturate pollen grains (6-8-colporate), not observed in the present study, and by lower values of polar and equatorial diameters. This fact demonstrates the existence of a morphological variability among pollen grains of different specimens of $S$. rugosa.

Guinet and Caccavari (1992) considered the pollen morphology of 27 South American Stryphnodendron species, grouped according to pollen types. The basic $S$. adstringens group comprised 12 species, presenting polyads ranging of up to $40 \mu \mathrm{m}$, always with 16 pollen grains covered with very small verrucae. Although the dimension of the major axis of the polyads was higher in our specimen, all the features presented by the authors agree with ours, demonstrating the constancy of the pollen characteristics of these species.

Zornia diphylla has been palynologically studied by Melhem (1966) and Salgado-Labouriau
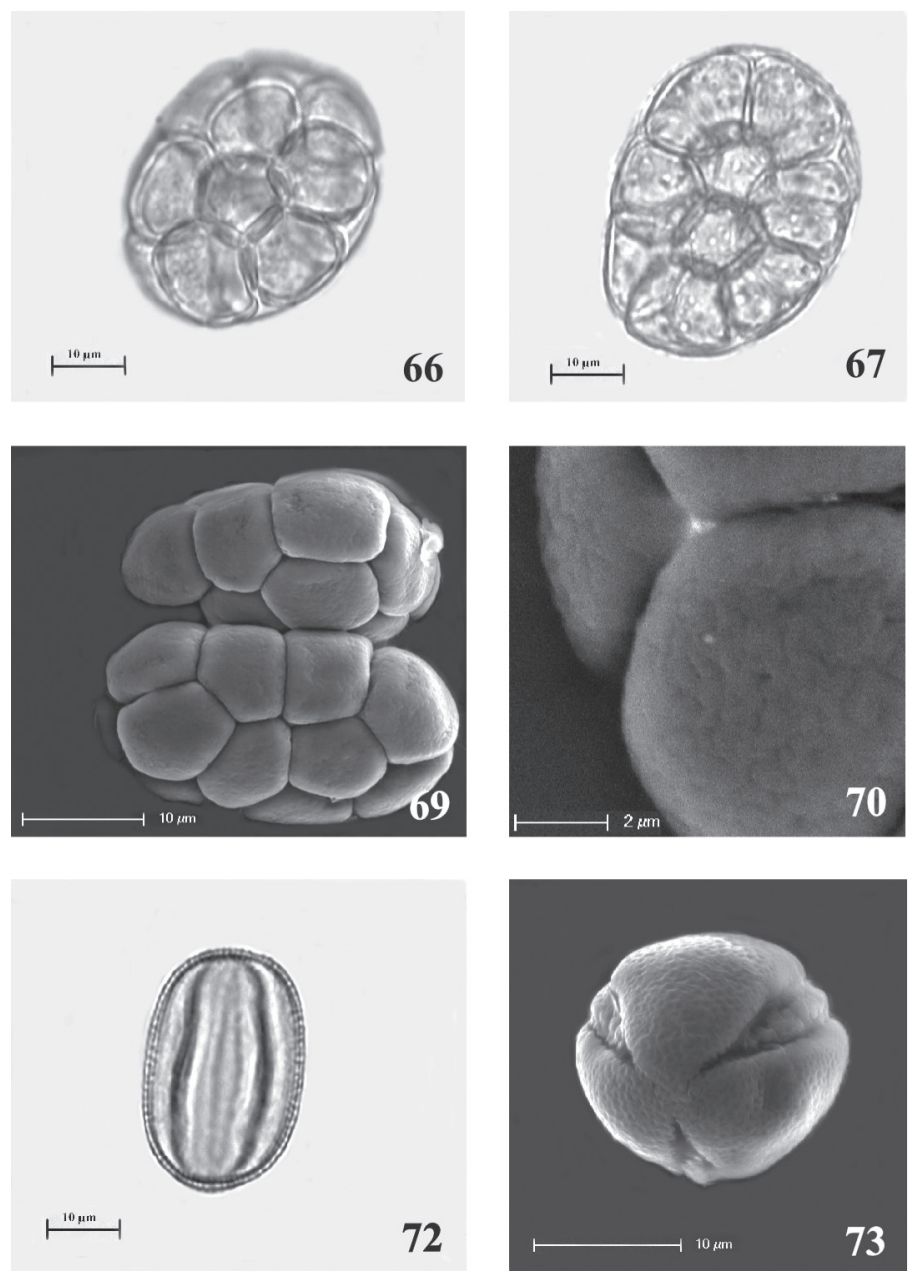
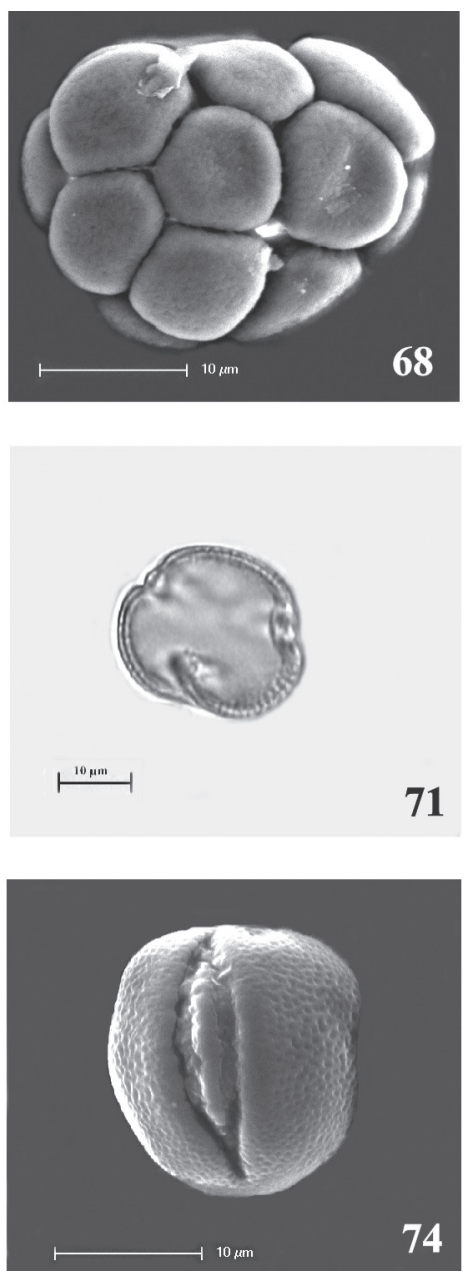

Figures 66-74 - Light and scanning electron micrographs of pollen grains of Stryphnodendron adstringens and Zornia diphylla. 66-70. Stryphnodendron adstringens (Mart.) Coville. 66. Front view of the polyad, optical section, LM. 67. Side view of the polyad, optical section, LM. 68. Side view of the polyad, SEM. 69. Geral view in two polyads, SEM. 70. Detail of ornamentation, SEM. 71-74. Zornia diphylla (L.) Pers. 71. Polar view, optical section, LM. 72. Equatorial view, optical section, LM. 73. Polar view, SEM. 74. Equatorial view, SEM. Scale bar $=2 \mu \mathrm{m}(70) ; 10 \mu \mathrm{m}(66,67,68,69,71,72,73,74)$. 
(1973). The descriptions presented differ from our specimen by a reticulate exine ornamentation, that is microreticulate of the present specimen, and smaller sizes of polar and equatorial diameter. Other species of Zornia were analyzed by SilvestreCapelato and Melhem (1997), Pire (1974), Carreira et al. (1996), Souza et al. (2004) and Moreti et al. (2007a), presenting a similar pollen morphology, except of 3-colporate pollen grains described by Carreira et al. (1996) and Moreti et al. (2007), and by the reticulate pattern described by SilvestreCapelato and Melhem (1997) and Moreti et al. (2007a). Several authors agree in common that this genus is stenopalynous, so it is not possible to separate the species into a pollen key.

\section{ACKNOWLEDGMENTS}

To the Conselho Nacional de Desenvolvimento Científico e Tecnológico (CNPq) for the fellowship of "Produtividade em Pesquisa" (Process number 301220/2009-3) to the first author. We also thank Dr. José Ivanildo de Souza from the Instituto de Botânica for lending the microscope LEICA DM 2500. We are thankful to Luciana Benatti for the electron micrographs.

\section{RESUMO}

O presente trabalho apresenta a morfologia polínica de treze espécies pertencentes a sete gêneros da família Fabaceae ocorrentes na Área de Proteção Especial Pau-deFruta, Diamantina, Minas Gerais, Brasil. Os grãos de pólen das seis espécies de Chamaecrista [C. cathartica (Mart.) H.S. Irwin \& Barneby, C. debilis Vogel, C. flexuosa (L.) Greene, C. hedysaroides (Vogel) H.S. Irwin \& Barneby, C. glandulosa (L.) Greene e C. papillata H.S. Irwin \& Barneby] apresentam morfologia similar, caracterizados por 3- longos cólporos constritos na região central. As espécies compartilham características morfológicas específicas em relação ao tamanho dos grãos de pólen, tipo de endoabertura (circular, lalongada ou lolongada) e padrão de ornamentação da exina em MEV (rugulado com perfurações ou perfurado). Andira fraxinifolia
Benth., Dalbergia miscolobium Benth, Galactia martii DC, Periandra mediterranea (Vell.) Taub., Senna rugosa (G.Don) H.S. Irwin \& Barneby e Zornia diphylla (L.) Pers apresentaram tipos polínicos diferenciados com tamanho de pequeno a grande; forma oblato esferoidal a prolata; aberturas em colpos ou cólporos; endoabertura circular, lalongada ou lolongada, e distintos padrões da ornamentação da exina em MEV (perfurado, microreticulado, reticulado ou rugulado com perfurações). Apenas Stryphnodendron adstringens (Mart.) Coville apresentou políades. A variação morfopolínica das espécies estudadas permitiu caracterizar a família Fabaceae como euripolínica na APE Pau-de-Fruta.

Palavras-chave: Serra do Espinhaço Meridional, Fabaceae, palinologia, morfologia polínica.

\section{REFERENCES}

APG II. 2003. An update of The Angiosperm Phylogeny Group classification for the orders and families of flowering plants. Bot J Linn Soc 141: 399-436.

APG III. 2009. An update of the Angiosperm Phylogeny Group classification for the orders and families of flowering plants. Bot J Linn Soc 161: 105-202.

Barroso GM, Peixoto AL, Costa CG, ichaso ClF, Guimarães EF AND Lima HC. 1991. Sistemática das angiospermas do Brasil. $2^{\mathrm{a}}$ v., UFV, Viçosa, Minas Gerais, p. $15-100$.

BARTH OM. 1964. Catálogo Sistemático dos polens das plantas arbóreas do Brasil Meridional-V. Leguminosae: Papilionatae. Mem I Oswaldo Cruz 62: 95-133.

BARTH OM AND MELHEM TS. 1988. Glossário Ilustrado de Palinologia. Editora Unicamp, Campinas, 75 p.

CAMPOS JRR, SILVAAC, VASCONCELLOS LL, SILVADV, Romão RV, SILVA EB AND GRAZZIOTTI PH. 2010. Pedochronology and development of peat bog in the Environmental Protection Area Pau-de-fruta - Diamantina, Brazil. Rev Bras Cienc Solo 34: 1965-1975.

CARreIRA LMM, Silva MF, LOPES JRC AND NASCIMENTO LAS. 1996. Catálogo de pólen das Leguminosas da Amazônia Brasileira. Belém: Bol Mus Para Emílio Goeldi, Coleção Adolpho Ducke, 137 p.

ERDTMAN G. 1960. The acetolysis method. A revised description. Svensk Botanisk Tidskrift: 561-564.

Funch LS AND WATANABE HM. 1994. Morfologia dos grãos de pólen do gênero Periandra Mart. Ex Benth. (Leguminosae, Papilionoideae, Phaseoleae). Rev Bras Bot 17: 105-112.

GUINET PH AND CACCAVARI MA. 1992. Pollen morphology of the genus Stryphnodendron (Leguminosae, Mimosoideae) in relation to its taxonomy. Grana 31: 101-112. 
HORAK I. 2009. Relações pedológicas, isotópicas e palinológicas na reconstrução paleoambiental da turfeira da Área de Proteção Especial (APE) Pau-de-Fruta, Serra do Espinhaço Meridional - MG (Tese de Mestrado). Piracicaba, Escola Superior de Agricultura Luiz de Queiroz/USP, 281 p. (Unpublished).

LeWIS G, Schire B, MACKINDER B AND LOCK M. 2005. Legumes of the World. Roy Bot Gard Kew, 577 p.

Melhem TS. 1966. Pollen grains of plants of the "Cerrado". XVII - Leguminosae- Lotoideae: tribe Hedysareae. An Acad Bras Cienc 38: 485-495.

MELHEM TS. 1968. Pollen grains of plants of the "Cerrado". XX - Leguminosae- Lotoideae: tribe Dalbergieae. An Acad Bras Cienc 40: 77-89.

MELHEM TS. 1971. Pollen grains of plants of the "Cerrado"Leguminosae - Lotoideae. Tribe: Phaseoleae. Hoehnea 1: 119-151

MENDONÇA FILHo CV. 2005. Vegetação. In: SILVA AC, PEDREIRA LCSF and ALMEIDA ABREU PA. Serra do Espinhaço Meridional: Paisagens e ambientes. O Lutador, Belo Horizonte, p. 19-43.

Moreti ACCC, FonseCA TC, Rodriguez APM, MONTEIROHARA ACBA AND BARTH OM. 2007a. Fabaceae forrageiras de interesse apícola. Aspectos botânicos e polínicos. Série Pesquisa APTA, Boletim Científico 13, Instituto de Zootecnia, Nova Odessa, 98 p.

Moreti ACCC, FonseCA TC, RODRIGUEz APM, MONTEIROHARA ACBA AND BARTH OM. 2007b. Pólen das Principais Plantas da Família Fabaceae com Aptidão Forrageira e Interesse Apícola. Rev Bras Bioci 5: 396-398.

Mori AM, Silva LAM, LisboA G AND CORADIN L. 1989. Manual de manejo do herbário fanerogâmico. Centro de Pesquisas do Cacau. Ilhéus, 104 p.

NeVEs SC, ABreu PAA AND Fraga LMS. 2005. Fisiografia. In: SILVA AC, PEDREIRA LCVSF and ABREU PAA. Serra do Espinhaço Meridional: Paisagens e Ambientes. O Lutador, Belo Horizonte. 47-58.

PIRE SML. 1974. Estudio palinologico de la tribe "Hedysareae" (Leguminosae). Bonplandia 3: 143-169.

PunT W, HoEn PP, BlackMORE S, NiLSSON S AND LE THOMAS A. 2007. Glossary of pollen and spores terminology. Rev Paleobot Palyno 143: 1-81.
RIBEIRO JF AND WALTER BMT. 1998. Fitofisionomias do Bioma Cerrado. In: Sano SM and Almeida SP (Eds), Cerrado: ambiente e flora Planaltina. EMBRAPA-CPAC: 89-166.

Roubik DW AND Moreno JEP. 1991. Pollen and spores of Barro Colorado Island. Monograph in Systematic Botany, St. Louis Missouri Botanical Garden Press 36, 268 p.

SAlgado-Labouriau ML, VANZOLINI PE AND MELhem TS 1965. Variation of polar axes and equatorial diameters in pollen grains of two species of Cassia. Grana 6: 166-176.

SALGADO-LABOURIAU ML. 1973. Contribuição à Palinologia dos Cerrados. Rio de Janeiro: An Acad Bras Cienc, 291 p.

Silva AC, Pedreira LCVSF AND Almeida ABreU PA. 2005 Serra do Espinhaço Meridional: Paisagens e Ambientes. Belo Horizonte, O Lutador, 272 p.

Silvestre-CAPELATO MSF AND MELhEM TS. 1997. Flora polínica da Reserva do Parque Estadual das Fontes do Ipiranga (São Paulo, Brasil). Família: 81 - Leguminosae. Hoehnea 24(1): 115-163.

Souza FC, Souza MA, MENdonçA CBF AND GONÇALVESEsteves V. 2004. Estudo polínico de espécies de Aeschynomeneae e Phaseoleae (Papilionoideae Leguminosae Juss.) ocorrentes nas restingas do Estado do Rio de Janeiro. Arq Mus Nac 62: 357-366.

SOUZA VC AND LORENZI H. 2005. Fabaceae (Leguminosae). In: Botânica Sistemática: guia ilustrado para identificação das famílias de Angiospermas da flora brasileira, baseado em APG II. Nova Odessa, SP: Instituto Plantarum, São Paulo. p. 291-328.

STIRTON CH. 1981. Petal sculpturing in papilionoid legumes. In: Polhimm RM and Raven PH (Eds), Advances in Legume Systematics. Roy Bot Gard Kew 2: 771-788.

WOJCIECHOWSKI MF. 2003. Reconstructing the phylogeny of legumes (Fabaceae): an early 21 st century perspective. In: Klitgaard BB and Bruneau A (Eds), Advances in Legume Systematics, part 10, Higher Level Systematic. Roy Bot Gard Kew: 5-35. 